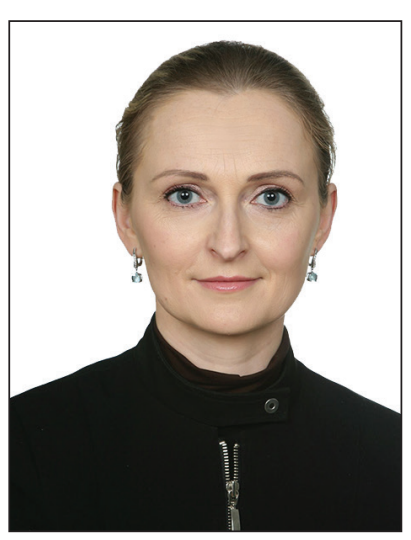

Mikalauskaitè-Šostakienè Kristina,

Doctoral Student,

Academy of Public Security (Lithuania),

Mykolas Romeris University,

Lithuania, Kaunas

e-mail:k_m_sostakiene@mruni.eu

doi: 10.21564/2414-990x.149.201730

UDC 349.414

\title{
THE OBJECTIVE NEED FOR LEGAL REGULATION OF TERRITORIAL PLANNING AND ITS IMPLEMENTATION IN THE REPUBLIC OF LITHUANIA
}

The article analyzes the social and legal assumptions that determine the need for the legal regulation of territorial planning. The extent to which the appropriate legal regulation of territorial planning is related to the protection of the environment, ensuring sustainable development and the protection of human rights is assessed. It is concluded that the process of territorial planning is complex and complicated, has different needs and interests of natural and legal persons regarding the use of the respective territories are constantly encountered. Although the reform of the legal regulation of territorial planning has been carried out three times in Lithuania, gaps in the legal regulation of territorial planning have been identified so far.

Keywords: territorial planning; legal regulation; sustainable development; environmental protection; Republic of Lithuania.

Мікалаускайте-Шостакієне К., аспірантка, Академія громадської безпеки, Університет Миколаса Ромеріса, Литовська Республіка, м. Каунас.

e-mail: k_m_sostakiene@mruni.eu

Об'єктивна потреба у правовому регулюванні територіального планування та його реалізація в Литовській Республіці

У статті проаналізовано соціально-правові передумови, що визначають необхідність правового регулювання територіального планування. Визначено, наскільки відповідне правове регулювання територіального планування пов'язане з захистом охорони навколишнього середовища, забезпеченням сталого розвитку та захистом прав людини. Зроблено висновок, що процес територіального планування є комплексним та складним, оскільки постійно виникають різні потреби й інтереси фізичних та юридичних осіб щодо використання відповідних територій. Хоча реформа правового регулювання територіального планування в Литві проводилася тричі, прогалини у ньому досі не подолано.

Ключові слова: територіальне планування; правове регулювання; сталий розвиток; захист навколишнього середовища; Литовська Республіка. 
Introduction. A human being is a part of nature. Without being in nature, without using its resources, a human cannot exist. Nature will always be the basis and source of human life [14, p. 13]. The growing number of people in the world is leading to the increasing use of natural resources and environmental pollution. Human activities have an impact on the environment, which is often negative, and the consequences of these activities are not always predictable [12, p. 11].

The last few centuries of world history have been known of scientific and technological achievements, population growth, and urban development, which are inevitably linked to human impact on the environment and natural processes.

People have acquired many instruments for modifying the environment to meet their needs in a variety of ways. Unfortunately, this is often associated with the pursuit of short-term benefits that can cause irreparable harm to both man and the environment.

In this way, a man has become not only the creator of his natural environment but also its destroyer. These circumstances determine the fact that natural resources must be used with the utmost care. The prudent use of natural resources means that natural resources must be used with care and responsibility concerning their limited nature. Rational use is economical to use, which means that measures must be taken to force the optimal use of natural resources and that no more than necessary would be used.

Prudent use and rational use cannot be strictly separated since they are related. They consist of the requirements for repeated, economical and sustainable use. An important aspect of prudent and rational use of natural resources is to ensure the long-term use of natural resources (both in quantitative and qualitative terms) so that future generations would have access to the same natural resources [6, p. 36]. Thus, in meeting its vital needs, today's society must live up to its duty and ensure that future generations could exercise their right to a healthy environment, which is suitable for living [33] ${ }^{1}$.

One of the necessary attributes of the State in the territory $[34]^{2}$. The objective of each state is to ensure the sustainable, purposeful and consistent development of the entire area of the State ${ }^{3}$. One of the most important and fundamental instruments that are a prerequisite for achieving this goal is proper, effective and efficient legal regulation of territorial planning. Society often does not appreciate the significance of territorial planning, although the surrounding environment and its quality have a significant impact on people's well-being and behaviour; therefore any, sometimes even minor changes to the legal regulation of territorial planning can have a

\footnotetext{
${ }^{1}$ Article 1.1 environment shall mean the totality of interconnected elements (land surface and subsurface, air, water, soil, flora, fauna, organic and inorganic matter, anthropogenic components) as functioning in nature and the natural and anthropogenic systems uniting them.

${ }^{2}$ Article 1 of the Montevideo Convention on the Rights and Duties of States defines the primary qualifications of the state: A permanent population; a defined territory; government; and capacity to enter relations with the other states.

${ }^{3}$ The territory of Lithuania is 65.286 square kilometres. URL: https://osp.stat.gov.lt/statistiniurodikliu-analize?hash=e7339206-858d-43de-ad93-f12ca772590c\#/.
} 
very significant effect on decision-making in the territorial planning process, that confirming the novelty and actuality of the topic.

When drafting territorial planning documents, it should be noted that the decisions contained therein will always affect people residing in the territory under concern or visitors, since the territorial planning documents affect the requirements for the newly developed areas, the revitalisation of current brownfields, and the like.

The future of the entire society and quality of residential environment depends on the capabilities to use the national territory, natural resources, develop cities, economy and infrastructure, to protect the landscape and cultural heritage. Therefore, the territorial planning process has recently received high focus and has been actively analysed concerning various aspects that are mainly oriented to the following specific areas: the general territorial concept of territorial development, land usage priorities, establishment of environment protection, monument protection and other conditions, the formation of land, forest, water use, residential areas, production and infrastructure systems. Without denying the importance of the above-mentioned areas, it shall be noted that quite often when the respective rights and obligations of the subjects of legal relations in the territorial planning process are enshrined in legal norms, it is not evaluated gratuitously, whether the Law establishes a suitable mechanism for persons to exercise these rights properly [7]. The latter forms the research problem. So in this research, the answer on does the current legal regulation of territorial planning ensures the implementation of legal functions, sustainable development and protection of human rights, is given.

In the course of reaching the objective of the research were employed the methods of systemic, analytical-critical, and linguistic analysis. Besides, the methods of documentary analysis and generalization were used.

\section{Proper and correct legal regulation of territorial planning as a precondition for ensuring sustainable development}

Today's society must live up to its duty and ensure that future generations could exercise their right to a healthy environment, which is suitable for living.

According to the theory of the division of human rights into three generations, the latter duty also has to do with the issues on the protection of human rights that are of increasing importance on a global scale. Considering that one of the essential obligations of a democratic state governed by law and justice is respecting, defending and protecting human rights and freedoms on which the Constitution adopted by the nation is based, and the real consolidation, defence and protection of which is the very raison d'etre [32] of the state, the state must ensure the protection of human rights for all three generations. Some authors attribute collective rights to the third generation, which are based on solidarity, the so-called 'solidarity rights': the right to development, the right to peace, the right to a healthy environment, and the right to the common heritage of humankind [16, p. 140]. A healthy human existence requires a healthy environment; therefore, a person shall be able to dwell in a healthy environment [2]. In this context, the proper and rational exploitation of 
resources is essential and essential not only for the members of the current society but also for future generations. It is one of the necessary conditions for guaranteeing the right to a healthy environment ${ }^{1}$.

The constitutional jurisprudence has pointed out on several occasions that land, forests, parks, water bodies are particular objects of property law, since the proper use and protection of land, forests, parks, water bodies is a condition for human existence, human and social survival and development, and for the well-being of the nation. According to the Constitution, natural environment, fauna and flora, individual natural objects, as well as areas of particular value, are national treasures of universal importance; their protection and ensuring the rational exploitation and enhancement of resources are public interest, which shall be guaranteed in terms of the constitutional duty of the state [27-31].

The behaviour of an individual may (but does not necessarily need to) be related to other individuals, but the individual can act in a way that does not only deal with other people, but also with animals, plants or items [3, p. 58]. In this context, it should be noted that quite often members of the public are trying to meet not necessarily their most important personal needs at the expense of others, thus denying the possibility of meeting the basic needs of those around them. The area of use of exploitation of resources ${ }^{2}$ is no exception. The extent of this problem is also exacerbated by environmental protection ${ }^{3}$ being, as mentioned before, not merely the priority of current society, but also cornerstone required for the proper realisation of the right to a healthy environment for future generations.

It is the society's need for the proper and rational use of natural resources that determines the necessity of legal regulation of public relations in this area, defining the basic rights and obligations of legal and natural persons in preserving biodiversity, ecosystems and landscape, ensuring a healthy and clean environment and rational use of natural resources.

The state must control the implementation of legal requirements in the field of environmental protection. This control is also known as ecological control. Ecological control is a function of state control and the legal institute of environmental law as well as the most important legal instrument ensuring the rational use of nature and protection of the environment against the negative impact [14, c. 449].

\footnotetext{
${ }^{1}$ The term 'healthy environment' implies certain qualitative characteristics that are reflected in the content of the term 'environment'. The term 'healthy environment' means that the environment is not harmful to the vital functions and the existence of human beings and other living organisms and therefore 'healthy environment' should be understood as an appropriate medium for human life and activities, as well as for the existence of other living organisms. G. Gaidys.

2 Article 1(3) of the Law on Environmental Protection of the Republic of Lithuania (Official Gazette 1992, No 5-75) defines natural resources as the elements of animate or inanimate nature (flora, fauna, including habitats, water, land (land surface and subsurface)) which are used or may be used by man for his needs;

${ }^{3}$ Article 1(2) of the Law on Environmental Protection of the Republic of Lithuania (Official Gazette 1992, No 5-75) defines environmental protection as the protection of the environment against physical, chemical, biological and another adverse effect or the consequences arising from the implementation of plans and programmes, pursuit of economic activities or utilisation of natural resources.
} 
However, for the control to be carried out, appropriate legal regulation must first be established. State involvement in the implementation of legal regulation means that the state primarily creates measures (legal norms) of legal effect on human behaviour, embodies in them a certain type of regulation of human behaviour (detailed or principled), as well as creates an institutional system to enforce and supervise this requirement [11, p. 206].

As regards proper regulation, it is important to note that it must be effective as well. The effectiveness of the law, like any other phenomenon, is inevitably measured by economic criteria (in the broad sense), measuring the progress made towards the goal. In other words, the law is socially effective if it helps to get closer to the goal, and is socially ineffective if it does not help to do so. In this sense, the effectiveness of a law is equivalent to the performance of the law. In turn, the performance of law can be measured as the ratio between the result sought and the result achieved or measured as purposefulness or expediency, i.e. measured not as much as through quantitative but rather by qualitative criteria, as approaching to the goal pursued.

In addition to performance, in many cases, there is a need for the criterion of law efficiency, which is an assessment of whether or not a law is effective in getting closer to the goal. It is true that efficiency is often equated with effectiveness and is considered by most sociologists of law as if it was detailed, concretised efficiency [9].

In this regard, the international community has been striving for many years to ensure sustainable development, with an appropriate legal regulation that guarantees the possibility to meet the needs of both current and future generations.

The concept of sustainable development was first introduced in 1987 in the report of World Commission on Environment and Development Our Common Future (also known as Brundtland report) ${ }^{1}$, which refers to sustainable development as development that meets the needs of the present without compromising the ability of future generations to meet their own needs; in pursuit of a better quality of life for everyone, now and for generations to come, economic, social and environmental goals are mutually supportive and complementary.

The basic principles of sustainable development were specified in the World Summit on Sustainable Development 1992, which took place in Rio de Janeiro and where Agenda 21, ${ }^{2}$ i.e. the programme of action for sustainable development worldwide, Rio Declaration on Environment and Development, and balanced principles of forest management were adopted.

In 2002, the United Nations organised the summit in Johannesburg to consider the changes that took place 10 years after the Rio de Janeiro Conference, as well as the goals achieved, and to revise perspective goals and objectives. To this end, the Johannesburg Declaration on Sustainable Development was adopted ${ }^{3}$.

\footnotetext{
${ }^{1}$ URL: http://www.un-documents.net/a42r187.htm.

${ }^{2}$ URL: https://sustainabledevelopment.un.org/content/documents/Agenda21.pdf .

${ }^{3}$ URL: https://ec.europa.eu/environment/archives/wssd/documents/wssd_pol_declaration.pdf.
} 
The European Regional/Spatial Planning Charter $^{1}$ (also known as the Torremolinos Charter) (hereinafter referred to as the Charter) was adopted in 1983 by the European Conference of Ministers responsible for Regional Planning. According to this Charter, territorial planning gives geographical expression to the economic, social, cultural and ecological policies of society. In this Charter, territorial planning is deemed to be a scientific discipline, an administrative technique and a state policy directed towards a balanced regional development and the physical organisation of space according to an overall strategy.

When analysing these documents, it is obvious that one of the ways to ensure the sustainable development of space is to establish proper and correct legal regulation of territorial planning. This is also the position of the Government of the Republic of Lithuania in the National Strategy for Sustainable Development ${ }^{2}$.

One of the most important and fundamental instruments to ensure the sustainable, purposeful and consistent development of the entire area of the State is proper, effective and efficient legal regulation of territorial planning.

\section{Territorial planning in lithuania after the restoration of independence: before, between and after reforms}

Territorial planning is subject to extremely complex tasks. First, at the microlevel, the interests of various stakeholders should be coordinated to minimise conflicts of interest in the planning of both brownfield and greenfield investment.

Second, at the macro level not only the international attractiveness of the whole state but, above all, that of the main cities (and in smaller states, at least one major city) should be boosted.

In this context, there is a significant problem in the complexity of the territorial planning process. At the micro-level, it is often aimed at introducing as many rules as possible to prevent conflicts with local communities opposing any changes.

The goals of the macro level are entirely different since any constraints mean lower investment attractiveness. Stagnation, constraints and rules lead to a defeat

\footnotetext{
${ }^{1}$ URL: https://rm.coe.int/native/09000016804c87cb.

2 Lithuania's Progress Strategy "Lithuania 2030" approved by Resolution No XI-2015 of the Seimas of the Republic of Lithuania of 15 May 2012 on the Approval of the National Progress Strategy "Lithuania 2030" and envisaging developments which will consolidate progress values and build on the principles of sustainable development; he National Development Programme 2014-2020 approved by Resolution No 1482 of the Government of the Republic of Lithuania of 28 November 2012 on the Approval of the National Development Programme 2014-2020, which provides for three horizontal principles (one of them being the principle of sustainable development) for the purpose of coordinating various initiatives to address comprehensive issues; the Programme of the Seventeenth Government of the Republic of Lithuania approved by Resolution No XIII-82 of the Seimas of the Republic of Lithuania of 13 December 2016 on the Programme of the Government of the Republic of Lithuania which identifies the development of sustainability as a fundamental goal implemented on five levels: sustainable human being, sustainable society, sustainable education and culture, sustainable economy and sustainable state governance; the first comprehensive national review on the implementation of the UN 2030 Agenda for Sustainable Development in Lithuania, as prepared by the Government of the Republic of Lithuania and successfully presented at the HighLevel Political Forum of the United Nations held on 16-18 July 2018 in New York (United States of America),
} 
in the global economic area. Finally, the community, the rights of which should have been secured by the said constraints, suffers the loss [4, p. 10-11].

After Lithuania had regained its independence, the issues related to territorial planning were in part regulated in a single legislative act - the Interim Regulations on Territorial Planning of the Republic of Lithuania, approved by the Decree of the Government of the Republic of Lithuania of 1993-03-12 [20]. In a few years, the Law on Territorial Planning of the Republic of Lithuania was adopted [21]. Considering the dynamics of social life, and changes caused by the interests of the state, society and individuals, this legislative enactment had been amended and supplemented 24 times. ${ }^{1}$.

The legislation of territorial planning in Lithuania had developed very intensively since the first stage of the modernisation, when the first Law on Territorial Planning of the Republic of Lithuania was adopted on 1 January 1996. However, the first wording of the law no longer met the needs of the developing legal relationships, even such abundant regulatory changes did not solve the problems arising in the process of territorial planning: the system of territorial planning remained complicated, including duplication of functions between public administration institutions, long procedural terms, an excess amount of documentation required from individuals, etc. [6].

In June 2013, the reform of territorial planning ${ }^{2}$ was carried out, and a new Law on State Supervision of Territorial Planning and Construction ${ }^{3}$ was adopted, laying down the procedure for the state supervision of territorial planning, supervisory authorities, their competence, duties and rights. The initiators and supporters of the reform were pleased that global problems in the field of territorial planning would finally be solved. However, the amended legal regulation does not address all the existing problems, but rather some and only formally, to the general extent. There is a clear need for further and more in-depth analysis of the regulatory framework and an adjustment procedure.

Thus, after the restoration of independence in Lithuania, the third and fundamental stage of the territorial planning reform was completed. The purpose of the current territorial planning is to ensure sustainable development of territories and rational urbanization; to determine the system requirements for the solutions of the territorial planning process, as well as the requirements for the compatibility and mutual impact of documents at different levels; to allow for the coherence of natural and anthropogenic environment, urban quality, safeguarding valuable landscapes, biodiversity, natural and cultural heritage.

${ }^{1}$ 2004-01-15 Was adopted new Law on Territorial Planning of the Republic of Lithuania. (Official Gazette. 2004, No. 21-617).

2 On 27 June 2013, the Lithuanian Parliament adopted the Law Amending the Law on territorial Planning of the Republic of Lithuania No XII-407, amending the Law on territorial Planning of the Republic of Lithuania.

${ }^{3}$ Teritorijų planavimo ir statybų valstybinès priežiūros įstatymas. (Valstybès žinios. 2013. Nr.76-3848). The Law on State Supervision of territorial Planning and Construction of the Republic of Lithuania. (Official Gazette. 2013. No 76-3848). 
However, the greatest challenge faced by both the legislator and the originator of territorial planning is to establish and ensure the procedure for the mutual coordination of different interests between various stakeholders. When considering any issues that arise in the process of territorial planning, it should not be forgotten that territorial planning is a process of compatibility between public and private interests. If only the private or the public interest is considered in all cases, the process cannot be defined as planning based on the principles of democratic society, prioritising compromises and rational, reasoned solutions that are in line with the principles of sustainable development and the requirements of the new urbanization movement rather than the interests of stakeholders.

The territorial planning process is complex and complicated, as the needs and interests of natural and legal persons concerning the use of the respective areas are constantly being faced. It is often in the interest of private persons to provide, in territorial planning documents, for conditions for the use and management of the area that is favourable to them and that is not at the best interests of the public.

The state, having a constitutional obligation to act in such a way as to guarantee the protection of the natural environment, its objects, the rational use, restoration and enhancement of natural resources, may by law establish such a legal regulation which would restrict the use of natural environment objects (natural resources), and would oblige certain legal entities to act accordingly or to refrain from certain actions.

While protecting the natural environment and its objects, the state, to ensure the rational use, restoration and enhancement of natural resources, must also guarantee the balance of the values enshrined in the Constitution.

The state, while regulating the relations related to the protection of the natural environment and its objects, the use, restoration and enhancement of natural resources, also by restricting the use of individual natural environment objects (natural resources) or obliging certain legal entities to act accordingly or to refrain from certain actions, is bound by the constitutional imperative of social harmony, the principles of justice, reasonableness and proportionality enshrined in the Constitution, inter alia when such restrictions or obligations interfere with the implementation of the constitutional rights and freedoms of a person [35].

According to Roscoe Pound, the sociological jurisprudence should ensure that social facts are considered in the creation, interpretation, and application of the law. This requires issues such as a descriptive study on the effectiveness of the rule of law, preliminary social research before the legislative procedure, a consistent study of the legal instruments, studies of sociological history, etc. Mr Pound, therefore, presents a law-oriented concept of social cohesion. The functions of the law and the means of its enforcement rise from rationalising legal rules and principles. In reconciling conflicting interests, the law shall ensure social cohesion and orderly social change; also, it must express a consensus and comply with the overriding public interest in ensuring that conflicts are resolved in an orderly manner and that the claim of each citizen can also be heard in court. Thus, according to Mr Pound, the legitimate 
purpose is to meet the needs of as many people as possible at the lowest possible cost [5, p. 608].

It is also important to note that the above-stated objectives of the reform on territorial planning, namely, to cut red tape, remove corruption, shorten procedures, remove duplication of functions and so on, are only formally and partially reflected in the new Law on Territorial Planning. Therefore, a more in-depth analysis allows the assumptions that these are just cosmetic adjustments to the legislation that do not deal with some of the problems in principle and leave room for legal loopholes to exist. This situation is not only flawed from a legal point of view but also creates the conditions for discrimination between the rights and interests of individuals, public confrontation etc.

As pointed out by A. Vaišvila, the social purpose of the law is a historical phenomenon that is changing, and this depends on changes in the concept of law, the relationship between social structure and social forces. If we rely on legal scrutiny, the social purpose of the law is to consolidate the will of the state and the economically and politically dominant group (class) of individuals standing behind it; and if we follow the concept of civil law, the purpose of the law is to protect the fundamental rights and freedoms of all members of society using equally effective measures [11, p. 156]. In principle, the institutions involved in territorial planning are not directly involved in the protection of human rights. However, the exercise of the functions and objectives assigned to these institutions cannot, in the event of regulatory dysfunction, affect the protection of human rights by expressing the dominance of the state (statism) over the individual. This would be utterly incompatible with the principle of the rule of law. It is therefore essential to examine what legal loops do not allow individuals to exercise their rights in the process of territorial planning properly and how the violated rights can be adequately protected.

The legal framework and the rule of law create a trend in society to maintain trust and security, to strengthen the concentration of society, which overrides and overstates the trend of demolition. This means that the legal framework, in interaction with moral, economic, political and other adjacent social systems, must fulfil the social purpose of the law, which emphasises: (1) protection and defence the fundamental human interests; (2) assurance of social and political cohesion of social groups; (3) promotion of the development of the quality of social coexistence in the society [10, p. 22].

Assuming that there are four methodological bases for sociology in law [17, p. 4-8], namely: (1) the difference between the legal and factual social relations, (2) the understanding and examination of the law as a social institution, (3) the internal strength of social arrangements, and (4) the dysfunction of the law, it is considered that all of them could potentially be used in the context of the dissertation research and scientific thesis.

Legal and factual social relations in the context of territorial planning are not always the same. Therefore, before establishing new or changing the existing 
legal regulation, it is expedient to analyse in which cases individuals, groups of individuals, with the help of law, acquire the opportunity to satisfy their interests at the expense of the rights and legitimate interests of other persons. Before establishing binding rules of conduct in the process of territorial planning, it is necessary to analyse the social relations that arise in the field of territorial planning and are seeking to be regulated by law. It is crucial to identify the real impact of the rules in this area, the direction of operation of public authorities, businesses and so on.

In regulating social relations, the law must guarantee social order and social stability, provide freedom with human content and human value [13, p. 94-94]. Due to the different objective and subjective circumstances, legal orders may not only fail to fulfil their functions, but rather disorganise social relations, not complying with the spirit of the time; the rules of law may be issued following the procedure laid down, but may not be implemented and become a simulated legal framework [13, p. 44], the 'absurd law' [15, p. 291-292]. With this in mind, while examining the functionality of the legal regulation of territorial planning, it is necessary to determine whether extending the boundaries of freedom in the process of territorial planning while ignoring social values, does not create the preconditions for the emergence of legal dysfunction ${ }^{1}$.

The forms of reasoning as an intellectual process do not always sit comfortably with the sources, forms, structures and language of the law. This is particularly true in the area of environmental governance. Although environmental governance is as old as any civilisation, it has only recently become a focus of the legal system as an element of public policy and public interest. Responding to the concepts of sustainability and sustainable development has become a doctrinal as much as a practical challenge for international, regional and national legal systems [1, p. 1].

Conclusions. After analysing national, international documents, it is obvious that one of the most important and fundamental instruments to ensure the sustainable, purposeful and consistent development of the entire area of the State is proper, effective and efficient legal regulation of territorial planning.

The necessity of regulation of territorial planning and territorial planning, in general, is indisputable, although it can be argued that the legal regulation in this field is the one that most restricts the right of ownership protected by the Constitution.

The search for the compromises between economic, environmental and social interests in territorial planning processes involves balanced development and ensures the preconditions for the realisation of the principle of legal security.

\footnotetext{
${ }^{1}$ The idea of the dysfunction of law was raised by Émile Durkheim because of the disorder of social relations - anomie. Anomie is a problem of social relations, social integration in society, due to the failure to comply with ethical, legal rules in times of severe social, political, and economic crises. However, anomie is also increasing in a context where the society is little concerned with the moral of individuals.
} 
After the restoration of independence in Lithuania, the third and fundamental stage of the territorial planning reform was completed in 2014. Even such abundant regulatory changes did not solve the problems arising in the process of territorial planning. Therefore, before establishing new or changing the existing legal regulation, it is expedient to analyse in which cases individuals, groups of individuals, with the help of law, acquire the opportunity to satisfy their interests at the expense of the rights and legitimate interests of other persons. Before establishing binding rules of conduct in the process of territorial planning, it is necessary to analyse the social relations that arise in the field of territorial planning and are seeking to be regulated by law.

\section{Bibliography}

\section{References}

1. Fisher, D. (2013). Legal Reasoning in Environmental Law: A Study of Structure, Form and Language. Cheltenham, UK Edward Elgar.

2. Gaidys, G. (2007). Žmogaus teisè ị sveiką aplinką: šios teisès atsiradimo ir formavimosi teisinès prielaidos Europos Sajungoje. Jurisprudencija, 3 (93), 61-68.

3. Kelzen, H. (2002). Grynoji teisès teorija. Vilnius, Eugrimas (in Lithuanian).

4. Klimas, E. (2017). Lietuvos Respublikos teritoriju planavimo įstatymo komentaras. The commentary on the Law of the Republic of Lithuania on Territorial Planning. Mykolo Romerio universitetas (in Lithuanian).

5. Pound, R. (2001). Philosophy of Law. Freeman M.D.A. Lloyds's Introduction to Jurisprudence. London: Sweet \& Maxwell.

6. Pranevičienė, B., Mikalauskaitė-Šostakienè, K. (2011). Problems of pre-trial investigation of legal disputes in the territorial planning. Jurisprudencija, 18 (3), 963-977.

7. Pranevičienè, B., Mikalauskaitė-Šostakienè, K., Vasiliauskienė, V. (2017). Territorial planning in Lithuania: the issues of security of society and interests of investors. Montenegrin journal of economics. Podgorica: Economic Laboratory for Transition Research, vol. 13, 3, 75-83 (in Lithuanian).

8. Ragulskytė-Markoviené, R. (2005). Aplinkos teisè: Lietuvos teisès derinimas su Europos Sajungos reikalavimais. Vilnius, Eugrimas (in Lithuanian).

9. Šimašius, R. (2004). Teisèkūra ir teisès socialinis veiksmingumas. Jurisprudencija, 54 (46), 62-73 (in Lithuanian).

10. Šlapkauskas, V. (2006). Teisinès sistemos disfunkcija - silpnos socialinès politikos požymis. Socialinis darbas. Mokslo darbai. Vilnius: Mykolo Romerio universitetas, 5 (1) (in Lithuanian).

11. Vaišvila, A. (2009). Teisès teorija. Justitia (in Lithuanian).

12. Venckus, Z. (2007). Aplinkos apsaugos politika ir teisè: Mokomoji knyga. Vilnius: Technika (in Lithuanian).

13. Alekseyev, S.S. (1998). Filosofiya prava. Istoriya i sovremennost. Problemy. Tendentsii. Perspektivy. Moscow: Norma. (Quoted from: Kazlauskienè, A., Petkus, A., Petkuvienè, R., Šlapkauskas, V. (2015). Teisés sociologija. Vilnius. Mykolo Romerio Universitetas (in Lithuanian).

14. Brinchuk, M.M. (1998). Ekologicheskoye pravo (pravo okruzhayushchey sredy). Moscow: Yurist (in Russian).

15. Karbonye, Zh. (1986). Yuridicheskaya sotsiologiya. Moscow: Progress. (Quoted from: Kazlauskienè, A., Petkus, A., Petkuvienė, R., Šlapkauskas, V. (2015). Teisès sociologija. Vilnius. Mykolo Romerio Universitetas) (in Lithuanian).

16. Lukasheva, E. A. (2004). Prava cheloveka. Moscow: Norma (in Russian).

17. Yuridicheskaya sotsiologiya. (2000). Moscow: Norma. (Quoted from Kazlauskienè A., Petkus A., Petkuvienė R., Šlapkauskas V. (2015). Teisés sociologija. Vilnius. Mykolo Romerio universitetas) (in Lithuanian). 


\section{Legal references}

18. Lietuvos Respublikos teritorijų planavimo ir statybos valstybinès priežiūros įstatymas. Valstybès žinios. 2013. Nr. 76-3848. [The Law on State Supervision of territorial Planning and Construction of the Republic of Lithuania. Official Gazette. 2013. No 76-3848].

19. Ruling of the Constitutional Court of the Republic of Lithuania of 20 May 2005. No. 14/02.

20. Lietuvos Respublikos Vyriausybės 1993 m. kovo 12 d. nutarimas Nr. 161 "Dèl Lietuvos Respublikos teritorinio planavimo". Valstybès žinios. 1993. Nr. 10-251. [Decree No. 161 of the Government of the Republic of Lithuania of Mart 12, 1993]; Official Gazette. 1993, No. 10-251].

21. Lietuvos Respublikos teritorijų planavimo įstatymas. Valstybès žinios. 1995. Nr. 107-2391. [Law on Territorial Planning of the Republic of Lithuania], Official Gazette. 1995, 107-2391].

22. Lietuvos Respublikos teritorijų planavimo įstatymas. Valstybès žinios. 2004. Nr. 21-617. [Law on Territorial Planning of the Republic of Lithuania. Official Gazette. 2004, 21-617].

23. Report of World Commission on Environment and Development Our Common Future. URL: http://www.un-documents.net/a42r187.htm (accessed 2020-02-02).

24. Rio de Janeiro and where Agenda 21. URL: https://sustainabledevelopment.un.org/content/ documents/Agenda21.pdf.

25. Johannesburg Declaration on Sustainable Development. URL: https://ec.europa.eu/ environment/archives/wssd/documents/wssd_pol_declaration.pdf.

26. The European Regional/Spatial Planning Charter. URL: https://rm.coe.int/ native $/ 09000016804 \mathrm{c} 87 \mathrm{cb}$.

27. The Constitutional Court of the Republic of Lithuania, Ruling of 13 May 2005, Case No 14/02.

28. The Constitutional Court of the Republic of Lithuania, Ruling of 13 May 2005, Case No 17/0224/02-06/03-22/04.

29. The Constitutional Court of the Republic of Lithuania, Ruling of 5 July 2007, Case No 03/0415/04-05/06;

30. The Constitutional Court of the Republic of Lithuania, Ruling of 6 September 2007, Case No 44/04-10/06.

31. The Constitutional Court of the Republic of Lithuania, Judgement of 4 July 2008, Case No 03/04-15/04-05/06.

32. The Constitutional Court of the Republic of Lithuania, Ruling of 19 August 2006, Case No 23/04.

33. Lietuvos Respublikos aplinkos apsaugos ịstatymo (Žin., 1992, Nr. 5-75) (Republic of Lithuania Law on environmental protection (Official Gazette, 1992, No. 5-75).

34. Montevideo Convention on the Rights and Duties of States. URL: https://treaties.un.org/ doc/Publication/UNTS/LON/Volume\%20165/v165.pdf (accessed 2020-02-02).

35. The Constitutional Court of the Republic of Lithuania, Ruling of 20 May 2005.

Микалаускайте-Шостакиене К., аспирантка, Академия общественной безопасности, Университет Миколаса Ромериса, Литовская Республика, г. Каунас.

e-mail: k_m_sostakiene@mruni.eu

Объективная потребность в правовом регулировании территориального планирования и его реализация в Литовской Республике

В статье анализируются социально-правовые предпосылки, определяющие необходимость правового регулирования территориального планирования. Определена степень, в которой соответствующее правовое регулирование территориального планирования связано с защитой окружающей среды, обеспечением устойчивого развития и защитой прав человека. Делается вывод, что процесс территориального планирования является комплексным и сложным, постоянно встречаются различные потребности и интересы физических и юридических лии, по использованию соответствующих территорий. Несмотря на то, что реформа правового регулирования 
территориального планирования в Литве проводилась трижды, проблемы в этой сфере до настоящего времени не преодолены.

Ключевые слова: территориальное планирование; правовое регулирование; устойчивое развитие; защита окружающей среды; Литовская Республика.

Рекомендоване цитування: Mikalauskaitė-Šostakienė K. The objective need for legal regulation of territorial planning and its implementation in the Republic of Lithuania. Проблеми законності. 2020. Вип. 149. С. 36-48. doi: https://doi.org/10.21564/2414-990x.149.201730.

Suggested Citation: Mikalauskaitè-Šostakienė, K. (2020). The objective need for legal regulation of territorial planning and its implementation in the Republic of Lithuania. Problemy zakonnosti Problems of Legality, issue 149, 36-48. doi: https://doi.org/10.21564/2414-990x.149.201730.

Надійшла до редколегї 28.04.2020 p. 